\title{
An Analysis of Factors Affecting the Company Performance in Creating the Competitiveness of Furniture and Printing Small-Sized Enterprises in Jayapura City
}

\author{
Mugiati \\ University of Science and Technology Jayapura, Indonesia \\ a.mugiati@yahoo.com
}

\begin{abstract}
This study aims to identify and analyze the influence of human resource management, production, marketing, working capital, organization, government policy, and competitor on the financial performance and competitiveness of Small-sized enterprise in Jayapura City. Data collection methods used were observation, interviews, and questionnaires, the number of samples is 258 Small-sized enterprises in Jayapura. Data were analyzed by applying SEM (structural equation modeling analysis method by making use of Amos Software. The results showed that the factors of production and government policy factors affect the financial performance and competitiveness of small-sized enterprise in Jayapura. While human resource management, marketing, organization and competitors factors affect the financial performance of small-sized enterprise in Jayapura, but does not affect the competitiveness of small-sized enterprise in Jayapura and working capital factor does not affect the financial performance of small-sized enterprise in Jayapura but affect the competitiveness of small-sized enterprise in Jayapura. Then the financial performance factor affects the competitiveness of small-sized enterprise in Jayapura.
\end{abstract}

Keywords: Company performance, Competitiveness, Small Sized Enterprises

\section{Introduction}

The economists argue that the small business sector has been proven to be durable of various economic conditions and able to with stand the various conditions of competition with great effort (Sasono, 2002). Tambunan (2002: 19) states that the performance of small and medium enterprises in Indonesia is still low. This is due tothe weakness of management, marketing, capital, technology and human resources owned by those small enterprises. While some expressed the opinion that the factors causing the lack of success of small enterprises is the in ability of the management, weaknesses in decision making, lack of experience, lack of financial oversight and the weakness in marketing (Scarborrough \& Zimmerer, 1993:38) In addition, in the courseof business undergone by a small company, it cannot be separated from the result of the policies and programs of government aid. But the Government's policy made indirectly has resulted in conditions that encourage to grow larger. This can be proven by many large companies that affiliate with small enterprises, especially small industrial goods so that small enterprises can run more efficiently. In the current competitive situation like this, an entrepreneur must be able to formulate in ternal strengths in business strategy by performing a combination of the opportunities and threats of the external environment. Until now it seems the conditions in small companies still have weaknesses in determining business strategic and tactic (Stifung, 1991:88).

Research aimed at small enterprises will always be relevant, because the sector development has been focused on the field of populist economic related to the relation between industry and agriculture. The main priority developed, among others, are by structuring the industry leading to the strengthening and deepening industrial structure which is supported by high-tech capabilities. Industrial development should be improved in order to become a major efficiency and high competitive booster of economic. Considering the significant of studying small enterprises, it is necessary toknow the level ofcompany's performance through strategic perspective approach. By knowingthe level of company's performance, it can be used as a guide for those who will participate in supporting small enterprises. This could be seen from an internal capability of each company group and the role of aid that has beengiven(based on internal conditions owned by each company), so that the description of what internal and external factors that are most dominant in managing small business development, especially in Jayapura city can be seen clearly.

Based on the description given on the background of the problems presented earlier, the main problem the research wants to find a solution and the answer can be formulated as follows: 
- Does human resource management factor affect the financial performance of small furniture and printing business in Jayapura city?

- Does human resource management factor affect the competitiveness of small furniture and printing enterprises in Jayapura city?

- Does production factor affect financial performance of small furniture and printing enterprisesin Jayapura city?

- Does production factor affect the competitiveness of small furniture and printing enterprises in Jayapura city?

- Does marketing factor affect the financial performance of small furniture and printing enterprises in Jayapura city?

- Does the marketing factor affect the competitiveness of small furniture and printing enterprises in Jayapura city?

- Does the financial factor affect the financial performance of small furniture and printing enterprises in Jayapura city?

- Does working capital factor affect the competitiveness of small furniture and printing enterprises in Jayapura city?

- Does the organizational factor affect the financial performance of small furniture and printing enterprises in Jayapura city?

- Does organizational factoraffect the competitiveness of small furniture and printing enterprises in Jayapura city?

- Does government policy factor affect the financial performance of small furniture and printing enterprises in Jayapura city?

- Does government policy factor affect the competitiveness of small furniture and printing enterprises in Jayapura?

- Does competitor factor affect financial performance of small furnitureandprinting enterprises inJayapura city?

- Does competitor factor affect the competitiveness of small furniture and printing enterprises in Jayapura city?

- Does financial performance affect the competitiveness of small furniture and printing enterprises in Jayapura city?

Based on the background of the study and the statements of the problem that have been described above, the overall objectives of this research are:

- To analyze and examine the effect of human resource management on the financial performance of small furniture and printing enterprises in Jayapura city.

- To analyze and examine the effect of human resource management on the competitiveness of small furniture and printing enterprises in Jayapura city.

- To analyze and examine the effect of production factor on the financial performance of small furniture and printing enterprises in Jayapura city.

- To analyze and examine the effect of production factors on the competitiveness of small furniture and printing enterprise in the city of Jayapura city

- To analyze and examine the effect of marketing factor on the financial performance of small furniture and printing enterprises in Jayapura city

- To analyze and examine the effect of marketing factor on the competitiveness of small furniture and printing enterprises in Jayapura city.

- To analyze and examine the effect of working capital on financial performance of small furniture and printing enterprises in Jayapura city.

- To analyze and examine the effect of working capital on competitiveness of small furniture and printing enterprises in Jayapura city.

- To analyze and examine the effect of organizational factor on the financial performance of small furniture and printing enterprises in Jayapura city.

- To analyze and examine the effect of organizational factor on the competitiveness of small furniture and printing enterprises in Jayapura city.

- To analyze and examine the effect of government policy on the financial performance of small furniture and printing enterprises in Jayapura city.

- To analyze and examine the effect of government policy on the competitiveness of small furniture and printing enterprises in Jayapura city. 
- To analyze and examine the effect of competitor factor on the financial performance of small furniture and printing enterprises in Jayapura city.

- To analyze and examine the effect of competitor on the competitiveness of small furniture and printing enterprises in Jayapura city.

- To analyze and examine the effect of financial performance on the competitiveness of small furniture and printing enterprises in Jayapura city.

\section{Literature Review}

Resource Based View of The firm (RBV) combines the company's internal analysis with external analysis of the industry and competitive environment. RBV can explain managerial technology. By applying RBV approach, the company will be able to identify objectively determinant in their competitive advantage. This is similar to the research conducted by the researcher of this study. The similarity deals with the quality and ability to compete. The result of Kwon \& Shin (2003) showed that Korean capital markets reflect macroeconomic variables such as production index, exchange rate, trade balance and the supply of money.Cheng (1996) found that there is a relationship between these factors and the capital market factors and economic forces both on the stock market in the UK and US.Pakpahan argued, written by Daulay et al. (2001:80), as he defined the ability to compete is competing measured by the cost of production. The lower per unit cost of production of a product is then it is said to have the competitiveness of the products produced.

Pablo(2003) divides the company valuation method into (1) a method based on balance sheet. (2) A method based on the income statement that is a multiple or a relative valuation, PER, sales and Price / EBITDA. (3) A method based on the goodwill that is the classical method. Performance measurement mechanism frequently used is financial ratio to look at the effectiveness and efficiency of the use of capital and according to Ruru (1995: 15), There are at least three reasons underlying the developing countries that recently considered the importance of the existence of UKM (SMEs/small and medium enterprises). Kuncoro (2000) mentions that small enterprise and home enterprise in Indonesia have played an important role in absorbing labor, increasing the number of business units and supporting the household income. Hunt (2004) stated that the flow of income (profit) generated by the operating companies, provide funds for future investment and give the company the ability to pay short and long term loans. This will result in higher profitability for the company.Baronet\&St-Pierre (2003) stated a positive relationship. Several researchers have looked at the relation between innovation and performance and its imp act on the competitive advantage (Hunt, 2004, Verhees \& Meulenberg, 2004).

\section{Methodology}

This study is trying to test the effect of the correlation between human resource management, production, marketing, finance, government policy organization, competitors on the performance of the company in improving the competitiveness of small enterprise in Jayapura city. This study used correlation analysis. Hypotheses are as follows:

- Human resource management factor affects the performance of small enterprise in Jayapura city.

- Human resource management factor affects the competitiveness of small enterprise in Jayapura city.

- Production factor affects the performance of the small enterprise in Jayapura city.

- Production factors affect the competitiveness of small enterprise in Jayapura city.

- Marketing factor affects the company performance of small enterprise in Jayapura city.

- Marketing factor affects the competitiveness of small enterprise in Jayapura city.

- Thefinancialfactoraffects theperformance ofthe smallenterprisein Jayapura city.

- Financial factoraffects thecompetitiveness ofsmall enterpriseinJayapura city

- Organizationalfactorsaffects theperformance ofthe small businessenterpriseinJayapura city

- Organizationalfactoraffects thecompetitiveness ofsmall enterprise in Jayapura city

- Government factoraffects theperformance ofsmall enterpriseinJayapura city.

- Thegovernmentfactoraffects thecompetitiveness ofsmall enterprise in Jayapura city.

- Competitor factor affects theperformance of small enterprise injayapura city.

- Competitor factoraffects thecompetitiveness ofsmall enterprise in Jayapura city.

- Performance factor affects the competitiveness of small enterprise inthe cityof Jayapura. 
The analysis method used is SEM using AMOS software. This study used Structural equation modeling (SEM), using the program Amos ver, it can explain the interrelationships among compound relationship simultaneously and the ability to assess the relationship comprehensively and led the research design changing from exploratory research into explanatory one (Hair, 1992).

\section{Figure 1: Conceptual Framework}

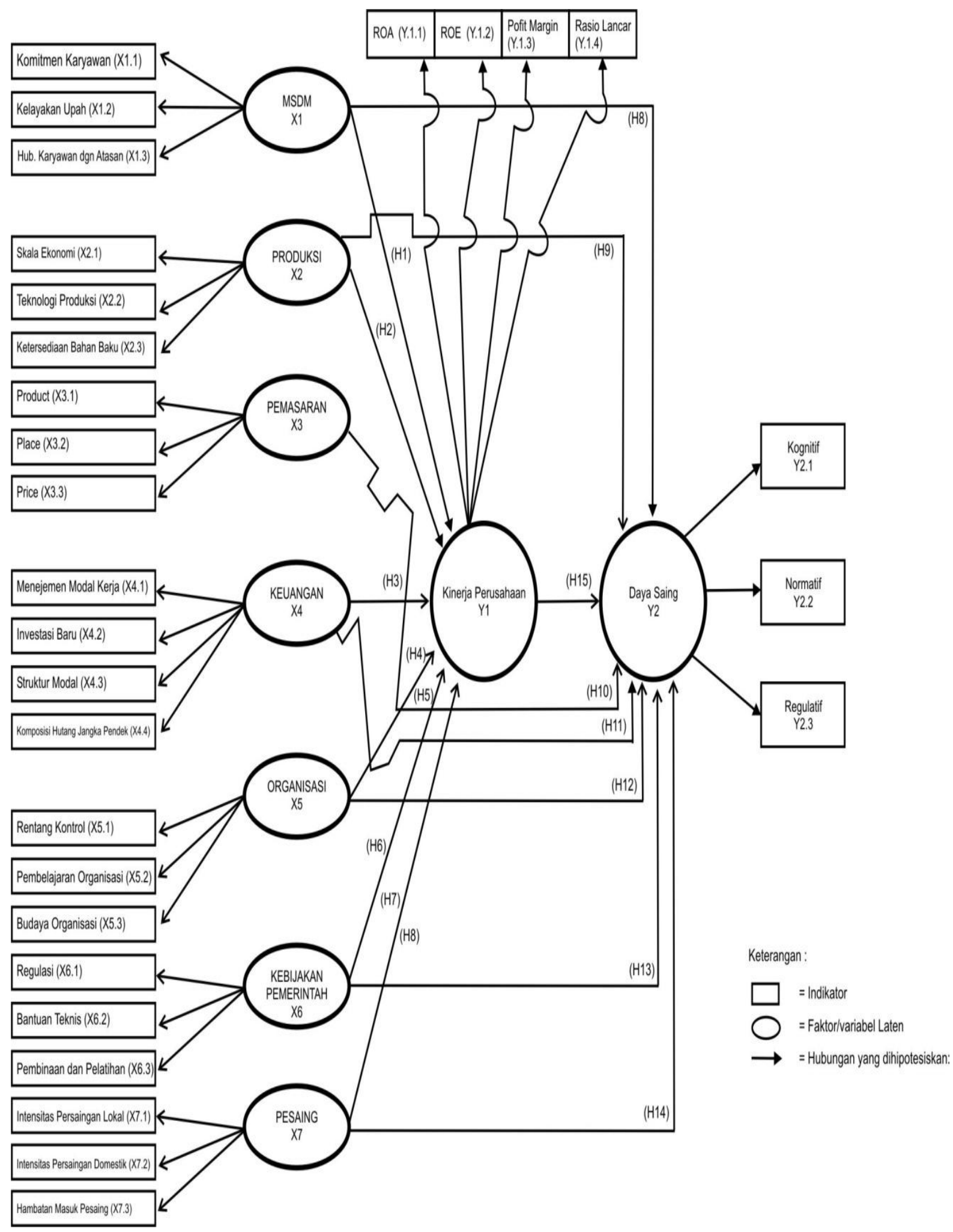


Table 1: Direct Effect

\begin{tabular}{|c|c|c|c|c|}
\hline No & Direct Effect & $\begin{array}{l}\text { Critical } \\
\text { ratio }\end{array}$ & Probability & Note \\
\hline 1 & $\begin{array}{l}\text { Human Resource Management Factor } \rightarrow \\
\text { financial performance }\end{array}$ & 1.253 & 0.210 & Not affected \\
\hline 2 & $\begin{array}{l}\text { Human Resource Management Factor } \rightarrow \\
\text { competitiveness }\end{array}$ & 4.006 & 0.000 & Affected \\
\hline 3 & 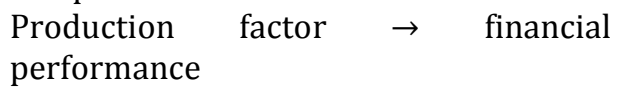 & 2.147 & 0.032 & Affected \\
\hline 4 & Production factor $\rightarrow$ competitiveness & 5.326 & 0.000 & Affected \\
\hline 5 & $\begin{array}{l}\text { Marketing factor } \quad \rightarrow \quad \text { financial } \\
\text { performance }\end{array}$ & 0.506 & 0.613 & Not affected \\
\hline 6 & Marketing factor $\rightarrow$ competitiveness & 2.449 & 0.014 & Affected \\
\hline 7 & $\begin{array}{l}\text { Working capital factor } \rightarrow \text { financial } \\
\text { performance }\end{array}$ & 9.492 & 0.000 & Affected \\
\hline 8 & $\begin{array}{l}\text { Working capital } \\
\text { competitiveness }\end{array}$ & 0.191 & 0.849 & Not affected \\
\hline 9 & Organizational factor $\rightarrow$ financial & -0.136 & 0.892 & Not affected \\
\hline No & Direct Effect & $\begin{array}{l}\text { Critical } \\
\text { ratio }\end{array}$ & Probability & Note \\
\hline 10 & $\begin{array}{l}\text { Organizational } \\
\text { competitiveness }\end{array}$ factor $\quad \rightarrow$ & -2.697 & 0.007 & Affected \\
\hline 11 & $\begin{array}{l}\text { Government policy factor } \rightarrow \text { financial } \\
\text { performance }\end{array}$ & -2.000 & 0.046 & Affected \\
\hline 12 & $\begin{array}{l}\text { Government policy factor } \rightarrow \\
\text { competitiveness }\end{array}$ & -3.468 & 0.001 & Affected \\
\hline 13 & $\begin{array}{l}\text { Competitor factor } \rightarrow \\
\text { performance }\end{array}$ & 1.514 & 0.130 & Not affected \\
\hline 14 & Competitor factor $\rightarrow$ competitiveness & 4.730 & 0.000 & Affected \\
\hline 15 & $\begin{array}{l}\text { Financial performance } \rightarrow \\
\text { competitiveness }\end{array}$ & 3.509 & 0.000 & Affected \\
\hline
\end{tabular}

Source: Analysis Results

Table 2: Indirect, Direct, Total Effects

\begin{tabular}{|c|c|c|c|c|}
\hline No & Direct Effect & $\begin{array}{l}\text { Indirect } \\
\text { effect }\end{array}$ & $\begin{array}{l}\text { Direct } \\
\text { effect }\end{array}$ & Total effect \\
\hline 1 & $\begin{array}{l}\text { Human Resource Management Factor } \rightarrow \\
\text { financial performance }\end{array}$ & 0 & 0.084 & 0.084 \\
\hline 2 & $\begin{array}{l}\text { Human Resource Management Factor } \rightarrow \\
\text { competitiveness }\end{array}$ & 0.020 & 0.298 & 0.318 \\
\hline 3 & $\begin{array}{l}\text { Production factor } \rightarrow \text { financial } \\
\text { performance }\end{array}$ & 0 & 0.138 & 0.138 \\
\hline 4 & Production factor $\rightarrow$ competitiveness & 0.034 & 0.393 & 0.426 \\
\hline 5 & $\begin{array}{l}\text { Marketing factor } \rightarrow \quad \text { financial } \\
\text { performance }\end{array}$ & 0 & 0.035 & 0.035 \\
\hline 6 & Marketing factor $\rightarrow$ competitiveness & 0.008 & 0.184 & 0.193 \\
\hline 7 & $\begin{array}{l}\text { Working capital factor } \rightarrow \text { financial } \\
\text { performance }\end{array}$ & 0 & 2.336 & 2.336 \\
\hline 8 & $\begin{array}{l}\text { Working capital } \\
\text { competitiveness }\end{array}$ factor $\rightarrow$ & 0.569 & 0.060 & 0.629 \\
\hline 9 & $\begin{array}{l}\text { Organizational factor } \rightarrow \text { financial } \\
\text { performance }\end{array}$ & 0 & -0.011 & -0.011 \\
\hline 10 & $\begin{array}{lll}\text { Organizational } & \text { factor } & \rightarrow \\
\text { competitiveness } & \end{array}$ & -0.003 & -0.234 & -0.237 \\
\hline 11 & $\begin{array}{l}\text { Government policy factor } \rightarrow \text { financial } \\
\text { performance }\end{array}$ & 0 & -0.125 & -0.125 \\
\hline
\end{tabular}




\begin{tabular}{lllll}
\hline 12 & $\begin{array}{l}\text { Government policy factor } \rightarrow \\
\text { competitiveness }\end{array}$ & -0.030 & -0.240 & -0.270 \\
13 & $\begin{array}{l}\text { Competitor policy factor } \rightarrow \text { financial } \\
\text { performance }\end{array}$ & 0 & 0.140 & 0.140 \\
14 & Competitor factor $\rightarrow$ competitiveness & 0.034 & 0.514 & 0.548 \\
\hline
\end{tabular}

Source: Result of ProcessedData

The analysis showed that the performance of the company does not give impact or indirect effect on all existing exogenous variables in the model. Therefore, the company performance has properties that"weaken" the relationshipbetweenexogenousvariablesandcompetitiveness. This is confirmedin the table below:

Table 3: The Impact of Indirect Effect of Intervening Variable

\begin{tabular}{|c|c|c|c|c|}
\hline no & Direct Effect & & Intervening Variable & Intervening Variable Effect \\
\hline 1 & $\begin{array}{l}\text { Human Resource Manage } \\
\text { Factor } \rightarrow \text { competitiveness }\end{array}$ & & financial performance & Weakening the Relationship \\
\hline 2 & $\begin{array}{ll}\text { Production } & \text { factor } \\
\text { competitiveness } & \end{array}$ & $\rightarrow$ & financial performance & Weakening the Relationship \\
\hline 3 & $\begin{array}{l}\text { Marketing factor } \\
\text { competitiveness }\end{array}$ & $\rightarrow$ & financial performance & Weakening the Relationship \\
\hline 4 & $\begin{array}{l}\text { Working capital factor } \\
\text { competitiveness }\end{array}$ & $\rightarrow$ & financial performance & Weakening the Relationship \\
\hline 5 & $\begin{array}{l}\text { Organizational factor } \\
\text { competitiveness }\end{array}$ & $\rightarrow$ & financial performance & Weakening the Relationship \\
\hline 6 & $\begin{array}{l}\text { Government policy factor } \\
\text { competitiveness }\end{array}$ & $\rightarrow$ & financial performance & Weakening the Relationship \\
\hline 7 & $\begin{array}{l}\text { Competitor factor } \rightarrow \\
\text { performance }\end{array}$ & & financial performance & Weakening the Relationship \\
\hline
\end{tabular}

Source: processedfromthe previoustable

\section{Hypothesis Testing}

H1:Human Resource Management Factor affects financial performanceis not proven.

H2: Human resource management affects the competitiveness of small enterprises in Jayapura cityis accepted.

H3: Production affects the financial performance of small enterprises in Jayapura city is accepted.

H4: Production affects the competitiveness of small enterprises in Jayapura city is accepted.

H5: Marketing affects the financial performance of small enterprises in Jayapura city is not proven

H6: Marketing affects the competitiveness of small enterprises in Jayapura city is accepted.

H7: Working capital affects the financial performance of small enterprises in Jayapura cityis accepted.

H8: Working capital affects the competitiveness of small enterprises in Jayapura city is not proven.

H9: Organization affects the financial performance of small enterprises in Jayapura city is not proven.

H10: Organization affects the competitiveness of small enterprises in Jayapura cityis accepted.

H11: Government affects the financial performance of small enterprises in Jayapura city is accepted.

H12: Government affects the competitiveness of small enterprises in Jayapura cityis accepted.

$\mathrm{H}$ 13: Competitor affects the financial performance of small enterprises in Jayapura city is not proven.

H 14: Competitor affects the financial performance of small enterprises in Jayapura cityis accepted.

H 15: Financial performance affects the competitiveness of small enterprises in Jayapura city is accepted.

Based on these results above, the overall model is shown in Figure 2 


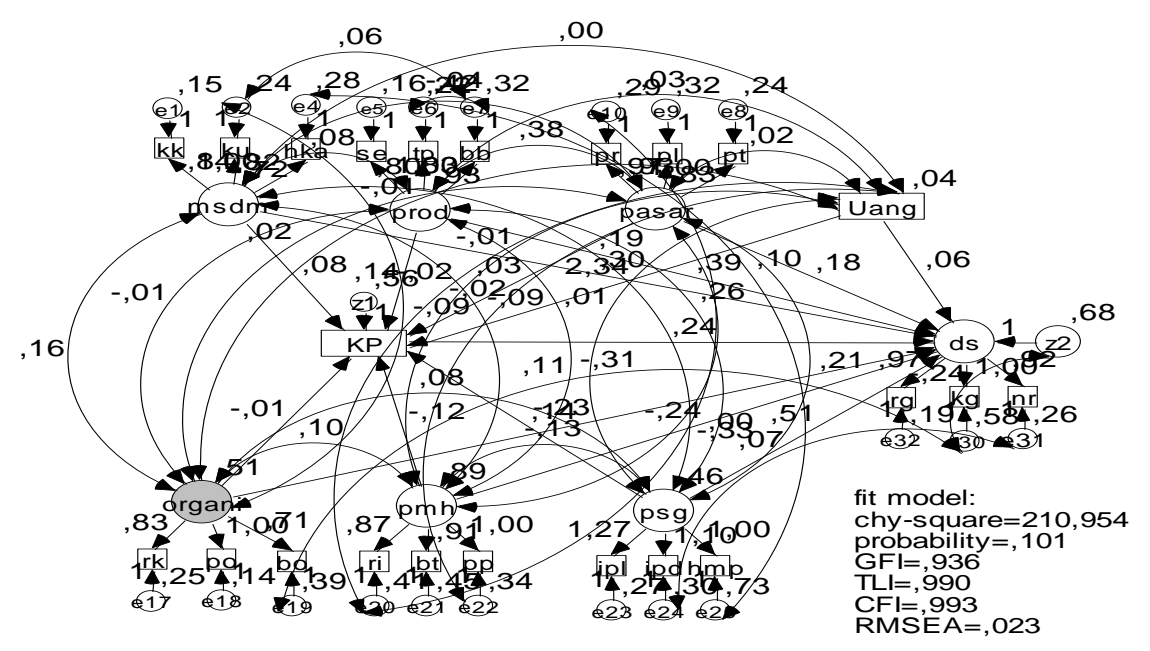

\section{Conclusion}

Based on theanalysisandverification and theprevious description, conclusionsandsuggestions can be formulatedasfollows:

- The human resource management factor is measured by using three indicators: employee commitment in which is high awareness of employees to always work well in accordance with job descriptions, wages eligibility which means compatibility between the remuneration given to the workload, as well as employee relationship with the boss is harmonious the relationship between employees and employers in the workplace. The research findings showed that human resource management has no effect on the financial performance of small businesses in the city of Jayapura. Typically, for the workers, many of whom have worked for such a long period. Therefore, the commitment, wages and relationship with the superior does not significantly affect the financial performance. Human resource management affects the competitiveness of small enterprises in Jayapura city. Human resource management, in the long term, will have an impact on competitiveness through working quality. Good working quality will have an impact on the working result or the produced product so that it will improve the competitiveness of small furniture and printing enterprises.

- Production factor is measured by three indicators, namely, economic scale that is low idle time on production equipment. The second indicator is production technology which means that the owner wishes to adopt the technology in the production process. The third is the availability of raw materials which is the availability of raw materials to support a smooth production process. Production of an effect on the financial performance of small furniture and printing business in the city of Jayapura. Production factors affect the competitiveness of small furniture and printing enterprises in Jayapura city.

- Marketing factor is measured by three indicators. The first is product. It is the suitabilitybetween the quality of products provided by the company with the quality that consumers expect. The second is place. Based on these three indicators of the research findings showed that marketing factors do not affect the financial performance of small furniture and printing enterprises in Jayapura city. Based on the observation of the indicator and marketing, then there are several possibilitycausing marketing factor does not partially affect significantly financial performance. First, the result of marketing success cannot be seen directly from accounting profit in the same period. Promotional activity, sacrifice to ensure image and brand of companies to consumers is example of indicators that relatively cannot generate profitability directly. Second, the relative financial performance cannot relatively measure the impact of marketing capabilities partially. Marketing affects the competitiveness of small furniture and printing enterprises in Jayapura city. Marketing capabilities will enhance the image and product innovation that in the long term will have an impact on the competitiveness of the company. 
- Working capital factor is measured by four indicators. Those indicators are first, working capital management. It is the amount of working capital divided by total assets. The second is new investment. It is additional new investments on average per year. The third indicator of capital structure is debt divided by assets, and the fourth indicator is composition of short-term debt. It is the short-term debt divided by total debt. Based on these four indicators, the research findings showed that working capital affects the financial performance of small furniture and printing enterprises Jayapura city. Although working capital affects financial performance, but the research findings showed that working capital does not affect the competitiveness of small furniture and printing enterprises in Jayapura city. It is due to the reason that for small enterprise, working capital factor is not the determinantcompetitiveness.

- Organizational factor is measured using three indicators. The first is control range. It is an effective ability of leadersto control their employees. The second is theorganization learning. It is the organization's will to always learn from failure. The third indicator is the organizational culture. It is the enterprise adoption of quality oriented values. Based on those indicators, the research findings showed that the organization has no effect on the financial performance of small furniture and printing enterprises in the city of Jayapura. These results indicate that control range, organizational learning and organizational culture do not have an impact on financial performance. Small furniture and printing enterprises also have cultural organization that does not develop properly so it does not affect the financial performance directly, but it affects the enterprise competitiveness. The ability of the organization, in the long term, will have an impact on competitiveness. Regular and systematic organization will increase the competitiveness of small furniture and printing enterprises.

- Government policy factor is measured by three indicators: regulation, coaching and training. Based on these three indicators, the research findings showed that government policies affect the financial performance of small furniture and printing enterprises in Jayapura city. However it has a negative coefficient. This means that an increase in the role of the government will make the financial performance of the enterprises decrease. The high role of government will make small enterprises become lulled because they expect too much to government instead of their own internal capabilities. If this condition occurs, the role of government in the form of assistance will degrade performance. The research findings showed that government policy affects the competitiveness of small furniture and printing enterprises Jayapura city. However, the coefficient is negative. This means that an increase in the role of the government will make the company into a declining competitiveness. Role of government will make small enterprises become lulled because they expect too much from the government instead of the internal capabilities. If this condition occurs, the role of government in the form of assistance will decrease competitiveness.

- Competitor factor is measured by three indicators: the intensity of local competition, the intensity of domestic competitionand the entering-barrier for competitor. It is the high of entering barrier for new competitor to industrial field. Based on these three indicators, the research findings showed that the competitor does not affect the financial performance of small furniture and printing enterprises in Jayapura city.. This is due to the fact that each unit of small enterprises has different consumer and the ability that is relatively similar so that the existing competitors will not affect financial performance. Competitor affects the competitiveness of small furniture and printing enterprises in Jayapura city. In the long term, the presence of competitors will have an impact on the enterprise competitiveness. This is in accordance with Porter's model of competitive advantage. He stated that the presence of new competitors and low barrier to enter the industry will have an impact on competitive advantage or competitiveness.

- Factors financial performance is measured by four indicators of ROA, ROE, profit margin and current ratio while competitiveness factor with cognitive indicators are individually leadership competencies in managing the business, then the second indicator, namely normative leadership capabilities in managing the organization well, the third indicator for competitiveness is regulative is the ability to try to determine the position of leadership as the best company at the industry level.

Based on these indicators the research findings showed that the company affects the competitiveness of small furniture and printing enterprises in Jayapura city. High financial performance will increase the business competitiveness. This means that businesses having high performance will make the business survive and exist easier. The company will also be able to survive and develop even though many 
competitors are entering. High financial performance makes the company financially sound and thus will increase the competitiveness of the company.

\section{Suggestion}

- It is expected that small furniture and printing enterprises in Jayapura city improve more efficiency and productivity that are done so that the selling price is relatively low while still maintaining product quality even with better quality, so that it is able to compete with the capabilities owned by company owner and it is followed by the owner's ability to do innovation of products produced by small furniture and printing enterprises.

- It is expected that small businesses in Jayapura city are able to develop capabilities in the field of informal education such as training for company owners and employees because having better knowledge combined with existing experience will produce better performance and increase competitiveness. Employers need to be provided expertise in the fields of management, marketing, finance and technology to face more competitive competition.

- It is expected that the government of Jayapura city is able to do empowerment of new entrepreneurship in which the direction is focused on trained and developed business practitionerdirection of the target offenders who nurtured and developed, so that the growth of new entrepreneurship will be able to increase labor and reduce unemployment. The assistance program in the form of training provided by the government of Jayapura city should be planned carefully to the needs in field of business without targeting on quantity but rather on the quality of the training itself.

- It is expected that the government of Jayapura city makes it easy for small furniture and printing enterprises in obtaining capital structure that is used so that the performance of small businesses in Jayapura city will be able to be superior and to develop, because it has a stronger capital structure. Small furniture and printing enterprises should always improve their own management capabilities, along with the growth of its business. They should be well-prepared in planning position rolling position to avoid industrial doubt the industry.

- Having been proved that factor production, working capital, and government policy factors affect the financial performance, therefore, the managers of small business furniture and printing enterprises should pay more attention to these factors on the financial performance. Negative influence factor that is government policy factor should be studied further, thus avoiding its impact on the company.

- Having been proved that the Human Resource Management, production, marketing, organization, government policy, competitor, and financial performance affect the competitiveness, the managers of small enterprises should pay more attention to these factors on its competitiveness. For negative influence factor that is government policy factor, it should be studied further, thus avoiding its impact on the company.

- Advanced research aimed to examine this area is suggested to expand population and sample in the area and the type of its business. The indicators provide an important role as indicators of the construct or latent variables should also be expanded.

\section{References}

Baronet, J. \& St-Pierre, G. (2004). Innovation in SMES: Who? What Kind? With What Effect? Preliminary Result of An Exploratory Study, University de Sherbrooke, Canada, 1-12

Cheng, A. C. S. (1996). Economics Factors And Stock Market: Empirical Evidence From The Uk And The Us, Journal of Finance And Economics, 2(1).

Daulay, P., Hotmatua, L. \& Lyanto, M. (2001). The ability to compete is measured by the cost of Hotmatua, Daulay, and Mulyanto, 2001.

Hair, F. H. A. (1992). Multivariate Data Analysis, MacMillan Publishing Company, New York.

Hunt, S. D. (2006). The Explanatory Foundations of Relationship Marketing Theory. Jurnal of Business and Industrial Marketing, 21(2), 72-87.

Kwon, S. C. \& Shin, T. S. (2003). Cointegration And Causality Between Macroeconomic Variables And Stock Market Return.

Pablo, C. (2003). The Influence of Social Work Exchange Relationship on Organizational citizenship behavior. Navara University. 497.

Ruru, B. (1995). BUMN policy direction Facing Era of AFTA in 2003 and EPEC 2020. Magazine of Management and Entrepreneurship, 9, 34-35. 
Sasono, A. (2002). Effects of Globalization on the Economy of Indonesia (Small Business Perspective MenengahFE Airlangga University, June 10, 2002, Surabaya.

Scarborough, N. M., Thomas, D. \& Zimmerer, W. (1993). Effective Small Business Management. New York: Macmillan Publishing Company.

Stifung, S. R. S. (1991). Research Training Needs for Small Industries in Bandung. Un-publised Research Report. Publisher ubuntu, Bandung.

Tambunan, T. T. H. (2002). Small and Medium Enterprises in Indonesia several important issues, Jakarta, Salemba Four.

Verhees, F. J. H. M. \& Meulenberg, M. T. G. (2004). Market orientation, innovativeness, product innovation, and performance in small firms. Small Business Management, 42, 134-154. 